Western University Scholarship@Western

Centre for the Study of International Economic Centre for the Study of International Economic

Relations Working Papers

Relations

1983

\title{
Border Tax Adjustments and U.S. Trade
}

Bob Hamilton

John Whalley

Follow this and additional works at: https://ir.lib.uwo.ca/economicscsier_wp

Part of the Economics Commons

Citation of this paper:

Hamilton, Bob, John Whalley. "Border Tax Adjustments and U.S. Trade." Centre for the Study of International Economic Relations Working Papers, 8317C. London, ON: Department of Economics., University of Western Ontario (1983). 
ISSN $\quad 0228-4235$

ISBN $\quad 0-7714-0454-9$

CENTRE FOR THE STUDY OF INTERNATIONAL ECONOMIC RELATIONS

WORKING PAPER NO. 8317 C

BORDER TAX ADJUSTMENTS AND U.S. TRADE

\author{
Bob Hamilton \\ and \\ John Whalley
}

This paper contains preliminary findings from research work still in progress and should not be quoted without prior approval of the author.

DEPARTMENT OF ECONOMICS

UNIVERSITY OF WESTERN ONTARIO

LONDON, CANADA

N6A 5 C 2

Department of Economics library

S.r zu 1983

University of Western Ontario 
Border Tax Adjustments and U.S. Trade ${ }^{1}$

Department of Economics Librany

SEP 201983

Bob Hamilton

University of Westem Ontario

John Whalley

University of Western Ontario

August 1983

1

We are grateful to the Social Sciences and Humanities Research Council, Ottawa, for financial support to seminar groups at Minnesota and NBER for comments, and to Charles Mclure and Melvyn Krauss for helipful suggestions. 


\section{Introduction}

This paper uses a numerical general equilibrium model of world trade and production to analyze the welfare and terms of trade effects on the U.S. of border adjustments in the indirect taxes used by major trading partners. The analysis is motivated by a number of current policy concerns over the border tax question, and the extent of trade advantage, if any, border adjustments abroad yield U.S. competitors.

In policy circles, the long-standing U.S. dissatisfaction with the destination basis in the EEC value added tax is both well known and widely documented. The same issue also arises with other U.S. trading partners, since both Japan and Canada use destination based indirect taxes. These issues have also crept into the debate in the U.S. on the possible introduction of a value added tax as part of the flat tax discussion, with a U.S. destination based VAT seen as a vehicle for retaliating against comparable taxes abroad. Finally, in the discussion of DISC, on which a GATT panel has ruled against the U.S., maintainence of DISC has sometimes been justified in the U.S. on the grounds that it offsets the trade advantages the EEC receives from their destination based value added tax.

In contrast, existing academic literature on the trade implications of the tax basis issue has focussed on neutrality propositions for switches between origin and destination bases in the uniform tax rate case, leading some academics to suggest that the border tax issue is of no importance. In practice, however, the taxes at issue are not uniform rate, making this area 
a natural target for a numerical general equilibrium approach, since the required theoretical structure is generally agreed but quantitative analysis is currently lacking.

While results indicate that the policy issues involved with these taxes are quantitatively small compared to wider issues of trade liberalization, a number of striking themes still emerge. Perhaps most important is the clear result that where the U.S. is a net importer of manufactures in trade, as occurs with Japan and the EEC, it is typically advantageous for the U.S. to have these countrles administer taxes on a destination rather than an origin basis, 1.e., not make the basis switch so often argued for in the U.S. This is because the taxes involved typically have higher rates on manufacturing rather than non-manufacturing products, and a discriminatory origin basis tax with higher rates on exportables operates akin to an export tax. In the case of Canada, however, from whom the U.S. is a net importer of raw materials and resources (rather than manufacturing), a basis switch does make sense from a U.S. viewpoint since the existing destination basis tax in Canada operates as a tariff.

An implication of these findings is that, given non-uniform tax rates abroad, adopting the same approach towards all trading partners on the tax basis issue is not in the U.S. national interest. A more flexible approach of considering trade with each partner on a bilateral basis; and separately negotiating border tax arrangements would be nationally preferred.

Policy Debates on the Tax Basis Issue

The main feature of the current set of indirect tax arrangements used by major U.S. trading partners is that each uses a national or federal destination basis broadly based indirect tax. While the U.S. does have federal excise taxes 
and statewide sales taxes, these are relatively insignificant compared with indirect taxes abroad. As a rough generalization, one can thus think of the U.S. as having no national broadly based sales tax, while all major U:S. trading partners do. The EEC has a destination based value added tax (VAT), Canada has a destination based manufactures sales tax, (MST), which combines with provincial retail sales taxes (PRST) which are more substantial than the statewide sales taxes in the U.S., and Japan has a destination based commodity tax (CT).

Under the destination basis in all these taxes, imports are taxed as they come into these countries while exports leave tax free. This contrasts. with an origin basis, under which imports are tax free but exports are taxed at point of production.

From a U.S. perspective the importance of this set of arrangements is the widespread perception that these countries receive an advantage in their trade with the U.S. The argument usually made is that U.S. exports have to cross a tax barrier in order to penetrate foreign markets, whereas foreign products entering the U.S. face no such barrier since they leave the country of production tax free. Put another way, these countries' products sell at gross of tax prices in their own countries, but at net of tax prices in the U.S. This perception of the tax basis in the U.S. has its origins in the 1960's with the introduction of the value added tax in the EEC, and persists up to the present day.

At the time when the EEC introduced the VAT, there was substantial discussion of these issues both in the academic and policy literature. In the policy arena, several different arguments were made in the U.S. These were all 
based on the premise that a situation with the U.S. operating no nationally based indirect tax, but with foreign countries having a destination basis in their taxes is disadvantageous to the U.S. One argument was that the U.S. should pressure its major trading partners to switch from a destination to an origin basis. This thesis was that an orlgin basis would be fairer since U.S. exports entering these countries would face no tax barrier, while products leaving these countries would be taxed at point of production and be treated on a comparable basis with their own products sold domestically. Another argument was that if foreign countries are unwilling to adopt an origin basis, the U.S. should countervail foreign destination basis taxes by adopting a similar destination basis tax of their own. This was part of the rationale given for the introduction of a value added tax in the U.S. in the early 1970's, even though the link between a destination basis and a value added tax does not necessarily hold, since a destination based federal sales tax, for instance, could be adopted.

More recently, this same set of concerns have arisen in two different guises, namely U.S. taxes and violation of GATT rules on export subsidies, and the flat tax debate. As is well known, the issue of whether the DISC represents an export subsidy has been referred to a recent GATT panel who have ruled against the U.S., suggesting the DISC should be removed. The U.S. has been reluctant to take any action on the DISC, and an argument heard in the U.S. is that it is necessary to keep the DISC in order to offset the trade advantage obtained from destination based indirect taxes abroad.

In the flat tax area, initial proposals have focussed on a simplified income tax, including expensing and an elimination of progressivity. Following the initial debates, however, it is now being recognized that an alternative way to achieve a similar result would be to switch to a consumption tax, and administer it as a value added tax. This is similar to the consumption tax proposals made by the Meade Committee in the U.K., except that in the case 
of Meade, progressivity was to be retained through a two tier tax. However, as soon as a flat rate value added tax is proposed to replace the income tax, it is natural for the debate once again to pick up the trade implications of such a change. An aspect of the flat tax debate now beginning to surface is the argument that the U.S. should use the opportunity of such a tax change to retallate against the foreign trading partners who have destination based indirect taxes.

In contrast to this policy debate, academics have, by and large, made little of the tax basis issue, because from the middle 1960's on they have concentrated their efforts on neutrality propositions for tax basis switches. These neutrality propositions examine a uniform tax rate case, and show that there are no real effects associated with a switch from an origin basis to a destination basis (see Shoup (1969), Shibata (1967), Krauss and Johnson (1970), Yeade (1974), and Grossman (1980)). In one case, taxes are collected at point of consumption, and in the other at point of production. If non-distorting taxes operate in either case, the only implication of a change in tax basis is to change the price level, which in the flexible exchange rate case also changes the exchange rate between domestic currencies. A change in tax basis can, therefore, take place with no real side long run equilibrium impacts; all that changes are exchange rates. Real trade flows, and relative commodity prices denominated in domestic currency remain unchanged as the tax . basis switch occurs. Many academics have therefore tended to view the policy debate on the tax basis issue in the U.S. as misguied because of these neutrality propositions. 
The weakness in the academic 1iterature is that the taxes at issue are not uniform rate taxes. The value added tax in the EEC, while originally proposed as a uniform rate tax with broad coverage, has degenerated into a system of multi-rate taxes, with significant differences between the various EEC countries. Similarly, in the Canadian case the federal manufactures sales tax is a tax explicitly on manufactures, and in the provinclal retail sales taxes this distinction between manufacturing and non-manufacturing is compounded through the exemption of food and housing. Equally, the Japanese based commodity tax is concentrated on manufactures. The academic literature has thus far not fully incorporated the discriminatory nature of these taxes abroad into the discussion of the relevance of the neutrality propositions to the policy debate on tax basis switches. It is widely acknowledged that in the case of non-uniform rate taxes the neutrality propositions in the literature break down, and Vandendorpe and Friedlaender (1968) have shown how a discriminatory output tax can improve a country's terms of trade. The implications of current tax policies in U.S. trading partners have not, however, been aumerfrally investigated; this is what we attenpt herc.

II Neutralities ali inn-Nintralities in Basis Switches.

Prior to discussing the numerical general equilibrium model of world trade used to analyze impacts of tax basis switches abroad in the non-uniform case, it is useful to review the neutrality arguments concerning basis switches in the uniform rate case, and offer some intuition as to what might happen in a nonuniform rate case.

To demonstrate neutrality for a basis switch we consider a situation in which there are two countries and two products, with each country completely specialized in production. $x_{1}$ is produced in country 1 , and $x_{2}$ in country 2 . 
Each country buys the products of the other; $x_{1}^{2}$ refer to exports by 1 to 2 , (country 2's imports); $x_{2}^{1}$ to exports by 2 to 1 , (country 1 's imports). $P_{1}$ and $P_{2}$ denote producer prices denominated in local currency, i.e. the prices received by sellers of products in their local currency; e denotes the exchange rate between currency 1 and 2 i.e., the price of a unit of $1^{\prime}$ 's currency in terms of 2's currency.

To demonstrate neutrality, we assume an equilibrium in the presence of one tax basis, and show that switching to the alternative tax basis has no effect on equilibrium relative prices:(and hence quantities). Two characteristics of equilibrium have to be shown to be invariant to the tax basis switch; the balance of payments condition, which we assume -also holds in the no tax case, and relative consumer prices in domestic currency in both countries, since these determine consumer demand behaviour. Uniform tax rates on both products apply, and revenues are redistributed in lump sum manner to a single domestic consumer. The equilibrium in the presence of taxes is thus also identical to that generated in no tax case.

Assume in the no tax case that a balance of payments condition holds, given by $\mathrm{P}_{1} \mathrm{x}_{1}^{2}=\mathrm{eP}_{2} \mathrm{x}_{2}^{1}$ which we denominate here, for convenience, in the currency of country 1. This implies that in domestic currency the value of exports is equal to the value of imports. Relative domestic currency denominated consumer prices in 1 are given by $\mathrm{P}_{1} / \mathrm{eP}_{2}$.

In the destination basis case, where the tax rate operates at rate $t_{1}$, the balance of payments condition will not change. Consumer prices are increased by a $\left(1+t_{1}\right)$ term in both the denominator and the numerator, which cancels leaving relative prices unchanged. The real characteristics of the no tax equilibrium thus remain unchanged.

With an origin basis tax, the balance of payments condition changes to $P_{1}(1+t) x_{1}^{2}=e_{2} x_{2}^{1}$. Because taxes are collected at point of production while 
iffports enter the country tax free, relative consumer prices in country 1 change to $\mathrm{P}_{1}(1+\mathrm{t}) / \mathrm{eP}_{2}$. If .we move from a destination to an origin basis, relative price levels (and thus the exchange rate) can adjust such that the balance of payments condition and relative consumer prices remain unchanged with the same $(P, X)$ vector. For this to occur, the exchange rate under the origin basis must equal that under the destination basis regime times $\left(1+t_{1}\right)$, i.e., $e^{0}=\left(1+t_{1}\right) e^{D}$, and the basis change is neutral in the sense that equilibrium trade flows are unchanged. The balance of payments conditions and domestic price ratios involved in these alternative equilibria are summarized in Table 1.

Neutrality can also be shown to hold in the more complicated case where intermediate:- production is present, as has been demonstrated by Grossman (1980). In this case the destination basis tax should apply to final sales onlyg and the origin basis tax only to value added. As in the case above, with intermediate production present the origin destination basis switch involves an adjustment in the exchange rate, giving neutrality for the basis switch in the uniform tax case.

The impacts of tax bases changes in the non-uniform tax case have not been fully discussed in the theoretical literature. There is some intuition, however, which can be gained from consideration of the non-uniform tax case for a small open price taking economy. In Figure 2, we analyze basis switches in the 2 commodity case for an economy which is a taker of prices on world markets. The country imports $\mathrm{X}_{2}$ and exports $\mathrm{X}_{1}$, and to simplify matters we consider a tax only on the import good $x_{2}$. To clarify the difference in impacts on trade flows between the two tax basis and a tariff, we also consider the case of a tariff on $\mathrm{x}_{2}$. 
Table 1

Balance of Payments Conditions and Relative Consumer Prices Under Tax Basis Switches

Balance of Payments Condition

No $\operatorname{Tax}$

Destination Tax in 1 (Rate $t_{1}$ )

Origin Tax in 1

(Rate $t_{1}$ )
Relative Consumer Prices in 1

$$
\begin{aligned}
& P_{1} / e^{N} P_{2} \\
& P_{1}\left(1+t_{1}\right) / e \cdot P_{.2}\left(1+t_{1}\right) \\
& P_{1}\left(1+t_{1}\right) / e^{0} P_{2}
\end{aligned}
$$

If $e^{0}=\left(1+t_{1}\right) e^{D}$, then the same balance of payments condition holds with unchanged $x_{2}^{1}, \dot{x}_{1}^{2}$, and relative consumer prices are unchanged. 


\section{Figure 2}

Impacts of Tax Basis Switches Under Non-Uniform Tax Rates

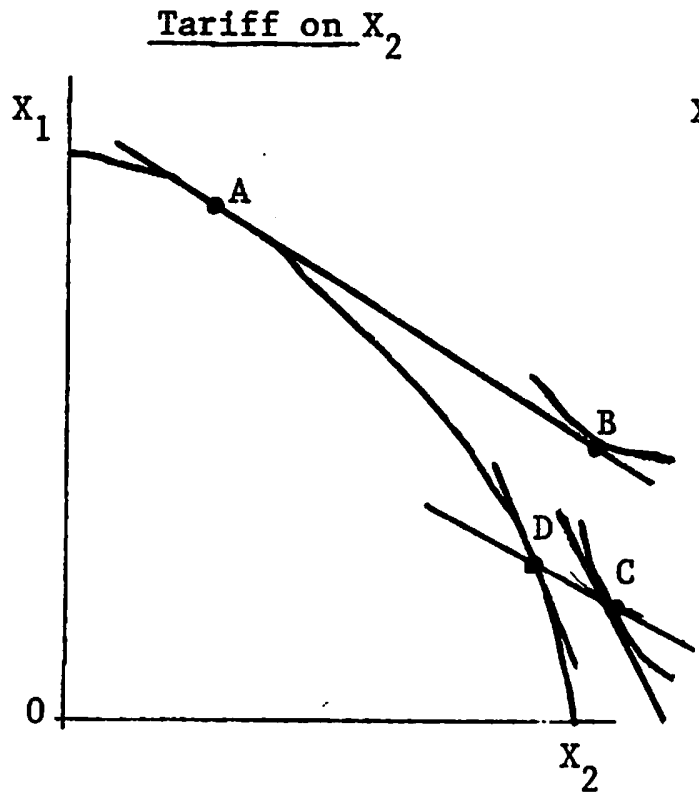

A,B - Free trade production, consumption

D,C - With tariff production, consumption

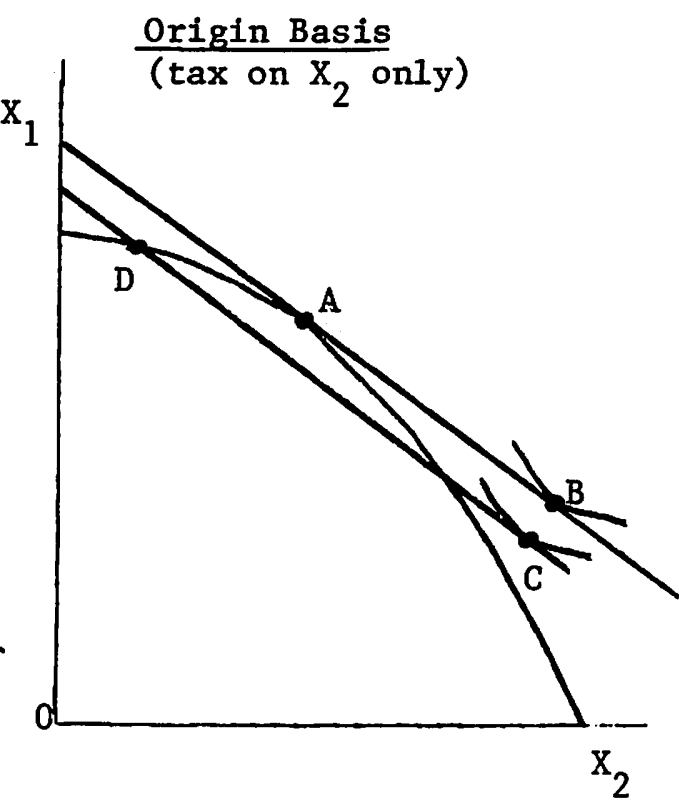

A,B - Free trade production, consumption

D,C - With tax production, consumption

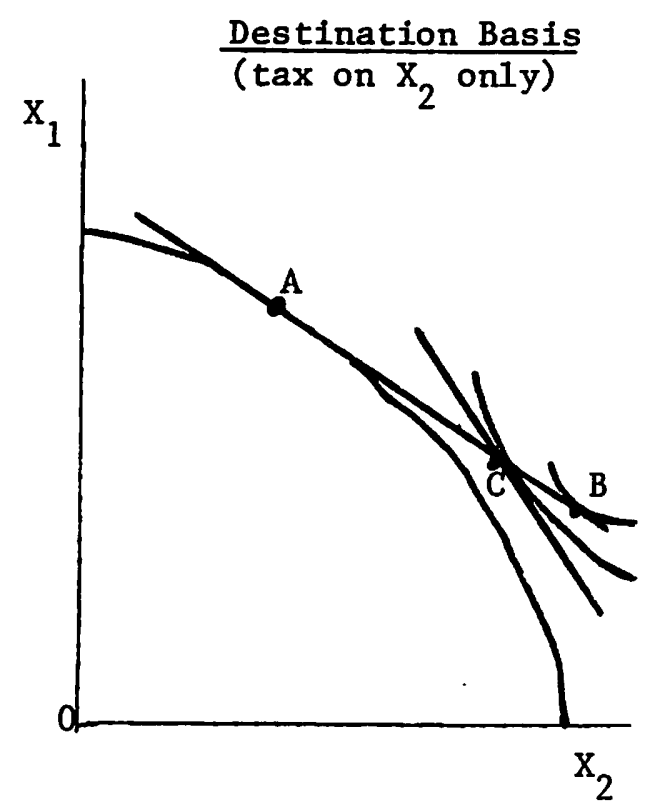

A,B,- Free trade production, consumption

A,C - With tax production, consumption 
As is well known, the effect of a tariff is to induce a domestic welfare loss which consists of two components; a production and consumption effect. Because domestic producer prices equal the gross of tariff prices, a domestic production distortion occurs moving production from point $A$ to point $D$, lowering potential real income. In addition, a domestic welfare loss occurs since consumption occurs at point $\mathrm{C}$ where an indifference curve is tangent to a domestic rather than a world price line.

Wreth non-uniform taxes administered on either an origin or destination basis, only one of the two effects associated with the tariff occurs. 'With the origin basis there is only a production effect, although in opposite direction to that associated with the tariff. With the destination basis tax only a consumption effect is involved.

This is represented in the second and third diagrams in Figure 2. With a tax on an origin basis, taxes occur at point of production and not at point of consumption. Imports enter tax free and consumption takes place at world prices since the tax is only on the imported good. However, because of the tax on domestic production of good 2, production moves from A to D. A loss in potential real income occurs, associated with the production effect of the distortion, but no consumption effect occurs. With a destination basis, taxes are collected at point of consumption rather than at point of production. No distortion of production occurs because any domestic production is sold at gross of tax prices, and net of tax producer prices equal world prices.

In these simple cases therefore, there is, a presumption that if an equal tax rate were involved in a basis switch, the welfare costs associated with either tax basis would be less than that due to a tariff.since only one of the two effects due to the tariff is present. This is ambiguous in the origin basis case, because of . the opposite direction of the production effect from that occuring with the tariff. 
While these diagrams clearly suggest a welfare effect associated with a basis switch in the non-uniform tax case, investigating their significance in more realistic settings requires a larger scale numerical general equilibrium model to which we now turn.

IV A General Equilibrium Model of World Trade ${ }^{1}$

The general equilibrium model used here to analyze impacts of basis switches abroad on the U.S. is based on that described in Whalley (1983). The present model variant differs from the earlier model in incorporating eight trading regions reflecting major participants in world trade in contrast to the earlier sevenand four-region versions of this model. These eight regions are the U.S., the EEC, Japan, Canada, Other Developed, Newly Industrialized, and Less Developed Countries. The size of these regions in the model reflects their relative U.S. dollar GNP for 1977 in the World Bank Atlas. 2

The model incorporates six products produced in each region. These are:

1. Agriculture and Food; 2. Mineral Products and Extractive Ores;

3. Energy Products (including oil); 4. Non-Mechanical Manufacturing;

5. Machinery and Transport Equipment (including vehicles); and

6. Construction, Services, and other Non-traded Goods. Each of the first

five goods are internationally traded with an assumed heterogeneity by region

$\because$ A more detalled description of earlier versions of the model incorporating only the EEC, the U.S., Japan and a residual rest of the world is given in Brown and Whalley (1980).

2 The conversion of country GNP data into U.S. dollars using the same exchange rates as in the World Bank Atlas should be noted as an important feature;which neglects differences between purchasing power parity and official exchange rates. 
prevalling across production sources. The sixth commodity is non-traded for all regions. The same commodity classification is used for trade, domestic production, and final demands, with an approximate concordance adopted between the different classification systems appearing in the basic data used. Problems of data availability for all regions plus the large dimensionalities involved in obtaining a general equilibrium solution for a eight-region model have limited the model to six products and eight regions; 48 products in total. The 'Armington' assumption of product heterogeneity by region implies that products are differentiated on the basis of geographical point of production as well as physịcal characteristics. 'Similar' products are sub'stitutes in both demand and production i.e.. Japanese manufactures are treated as qualitatively different praducts from U.S. or.EEC manufactures. This treatment is used both to accommodate the statistical phenomenon of 'cross-hauling' in international trade data, and to exclude complete specialization in production as a behavioural response in the model. This structure also enables empirically based import demand elasticities to be incorporated into the model specification.

Production and demand patterns in each of the iregions revolve around the domestic and world price systems. For each product in the model the market price is the price at point of production. Sellers receive these prices, purchasers (of both intermediate and final products) pay these prices gross of tariffs, NTB tariff equivalents, and domestic taxes; no transportation costs are considered.

Explicit demand functions are used for each region which are derived from hierarchical CES/LES preference functions, and CES functions characterize production sets. Producers maximize profits and competitive forces operate such that in equilibrium all supernormal profits are competed away. Investment flows, interest and dividends, and foreign aid also enter the model, with the second two of these being treated as income transfers. 
The model examines international trade equilibrium situations, where demands equal supplies for all products, and in each industry in each region a zeroprofit condition is satisfied representing the absence of supernormal profits. In equilibrium, a zero external sector balance condition (including investment flows, dividends, interest and transfers) also holds for each region.

An important feature of the model is the structure of substitution possibilities on both the demand and production sides, wich are represented by the CES and CES/LES functions. The elasticities of substitution in these functions determine price elasticities of goods and factor demands, and because of the Armington product heterogeneity assumption, these elasticities also control import and export demand elasticities for each region.

In production, each industry has a CES value-added production function which specifies substitution possibilities between the primary factor inputs, capital and labour services. No technical change is incorporated, and factors are immobile between regions. In addition to the CES value-added functions, each industry uses the outputs of other industries (both domestic and imported) as inputs in its own production process. Substitution between intermediate products is allowed while fixed coefficients in terms of composite goods are assumed. Each fixed coefficient requirement is specified in terms of a composite good,which itself is represented by a nested CES function with elements of the composite (i.e. products identified by geographical point of production) entering as arguments. Substitution occurs between comparable domestic and composite imported commodities at the top level of nesting, with further substitution taking place between import types differentiated by location of production. 
On the demand side, a single set of final demand functions for each region are obtained by maximizing a nested CES/LES utility function. Within this functional form, a hierarchy of substitution possibilities applies between similar products imported from the various regions, and between composites of imports across sources and comparable domestic products. Use of these nested functions enables empirical estimates of price and income elasticities in world trade to be incorporated into the model. These values guide parameter choice for inter-nest elasticity values in the CES functions (i.e., between 'similar' products subscripted by location of production). The LES features in the hierarchy allow income elasticities in import demand functions to differ from unity.

- Since each region generates demands from utility maximization, the market demand functions in the model satisfy Walras' Law. This is the condition that at any set of prices the total value of demands equals the total value of incomes. The incomes of regions are derived from the sale of primary factors owned by each region plus transfers received (including foreign aid). Finally, the model incorporates tariffs and non-tariff barriers (NTBs) in ad valorem equivalent form, along with domestic tax policies. With the exception of Canada, the parameter values adopted to represent these along with the sources used are given in Whalley (1983). By changing the model specification of tax rates, impacts of changes in tax bases can be considered by computing equilibria associated with alternative policy regimes.

V Benchmark Calibration, Elasticities and Equilibrium Solution of the Model

The procedures used in applying the model are outlined in Table 3. A worldwide general equilibrium constructed from 1977 data is assumed to hold in the presence of existing trade and tax policies. The model is calibrated to 
MODEL FLOW CHART FOR WORLD TRADE GENERAL EQUILIBRIUM MODEL

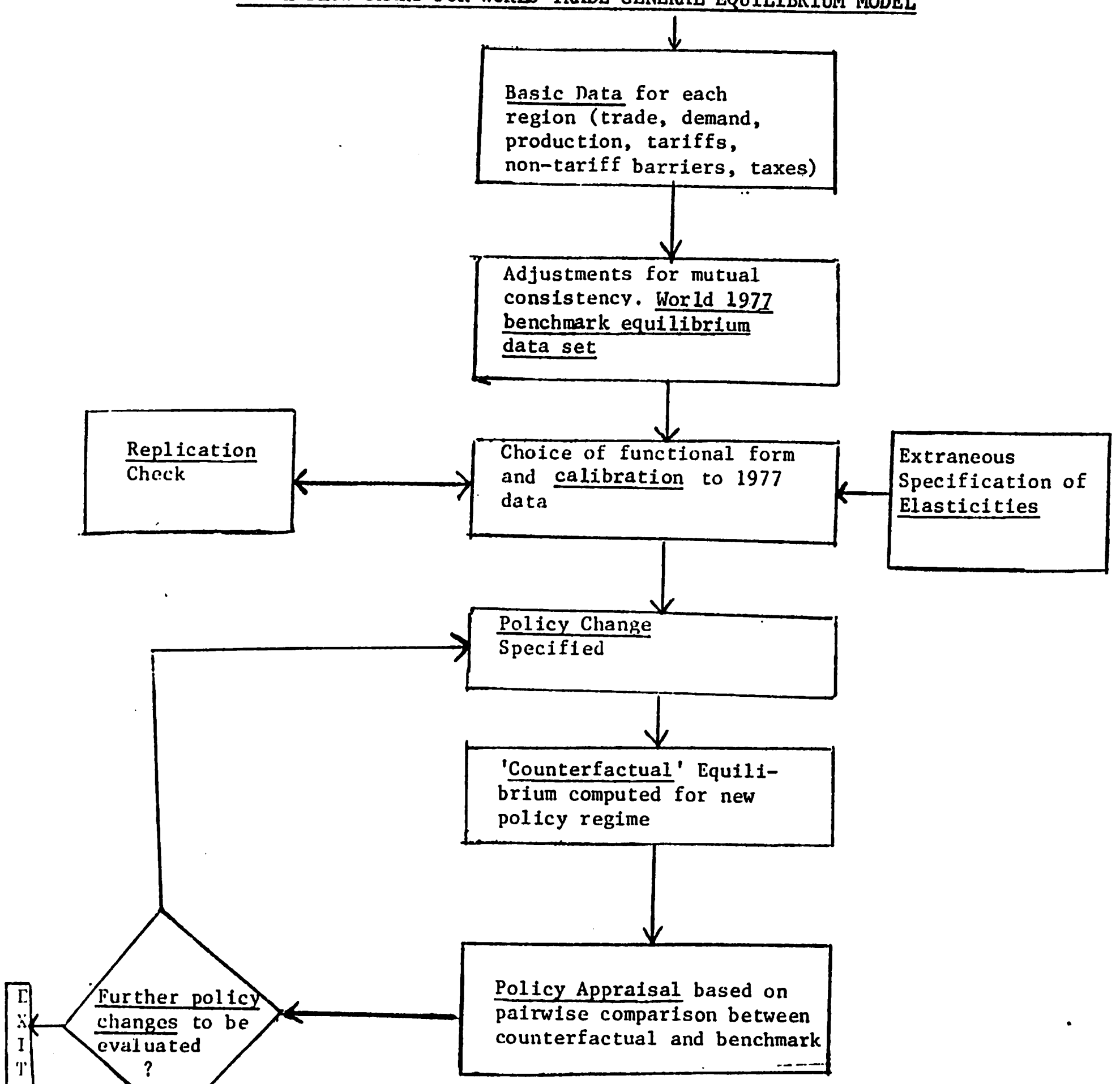


this data set through a procedure which determines parameter values for the model functions consistent with the equilibrium observation. Counterfactual analysis then proceeds for any specified policy change.

This calibration procedure involves first constructing a data set for a given year in a form which is consistent with the equilibrium solution concept of the model; a so-called benchmark equilibrium data set. Once assembled, parameter values for equations can be directly calculated from the equilibrium conditions using the calibration procedure described in Mansur and Whalley (1983). The model specification is then capable of reproducing the benchmark data as an equilibrium solution to the model. Comparative statics can be performed by computing new equilibria for alternative tax regimes, and comparing new and benchmark equilibrium data.

The micro consistent benchmark equilibrium data set constructed for this purpose has the properties of a worldwide competitive equilibrium in that demands equal supplies for all products, no profits are made in any of the domestic industries, and each region is in zero external sector balance. The data set involves both the domestic and trading activity of each of the regions, and a number of source materials are used which need adjustment for inconsistent classifications and definitions. A description of the methods used in assembling the 1977 data set used appears in Whalley (1983).

Parameter values, consistent with the equilibrium observation, are determined using the model equilibrium conditions and the benchmark data. Because of the CES/LES functional forms used, this procedure requires more information than that . contained in the benchmark equilibrium data set. This information requirement is met by specifying elasticities of substitution and minimum requirements in the functional forms. Once these are chosen, demand functions are solved for share 
parameters consistent with both equilibrium prices and quantities. On the supply side, cost functions are similarly solved for share and unit parameters consistent with equilibrium prices and input use by industry.

As might be expected, the values chosen for substitution elasticities have a substantial impact on the results produced by the model, and the procedure followed is to adopt a central case model specification around which sensitivity analysis can be performed. Given the present focus on trade effects of tax policies, an especially important set of parameters are the substitution elasticities which determine implicit trade elasticities. Import price elasticities for developed countries in the . model reflect the Stern, Francis, Schumacher (1976) compendium of trade elasticitles, and estimates for developing countries are due to Khan (1974). Recent estimates for the U.S., EEC, and Japan by Stone (1979) provide detailed estimates by product and are also approximately consistent with the values used in the model. The low values (in absolute terms) of import price elasticities produced by these and other studies have been extensively commented on in the 1iterature. $\quad$. In the present model these produce significant terms of trade effects from tax basis switches policy changes, and their role should thus be highlighted.

Once specified, the model is solved for a new general equilibrium for a policy or other change using a Newton method involving an estimate of the Jacobian matrix of excess factor demands and government budget imbalances. Although there is no ex ante argument of convergence with this Newton method, it has been. successful in implementation.

\section{Results and Policy Implications}

The numerical general equilibrium model described in the two earlier sections has been used to analyze a number of changes in indirect taxes in the EEC, Japan, Canada, and the U.S. These all involve modelling the tax change desired in a 
model equivalent form, introducing the changed tax regime into the model, and computing the new equilibrium associated with the policy change. Comparison between benchmark and counterfactual equilibria then provides the basis for the policy evaluation.

Table 4 reports welfare and terms of trade results under switches from the destination basis currently prevailing in the EEC, Japan, and Canada to an origin basis keeping tax rates unchanged. The welfare changes reported are Hicksian equivalent variations in 1977 billions of dollars, with a positive EV indicating a welfare improvement and a negative EV a welfare loss.

A number of striking results emerge from Table 4. The first is that in aggregate the effects involved are quite small. These are considerably smaller than those associated with changes in tariffs and non-tariff barriers in other work by the authors, and suggest that in aggregate the orders of magnitute involved with changes in tax bases may be less significant than those associated with larger moves toward trade liberalization. Indeed for the case where there is an EEC switch to an origin basis, the global impact (as given by the sum of $\left.E V^{\prime} s\right)$ is negative.

Beyond the small size of the aggregate effects, nhowever, other interesting features emerge. In the case of a switch in either the EEC or Japan to an origin basis from the existing destination basis, results indicate a significant welfare improvement for both the EEC and Japan and a welfare loss for the U.S. These are accompanied by terms of trade improvements for both the EEC and Japan, and a terms of trade worsening for the U.S.

The reasons these results are obtained is due to the structure of indirect tax rates in these two regions. Tax rates are heaviest on manufacturing products, 
Table 4

Switches to Origin Basis From Destination Basis

A. Annual Welfare Impacts (EV's in 1977 \$bill)

EEC Switch Japan Switch $\quad$ Canada Switch Al1 3 Switch

$\begin{array}{lrrrr}\text { EEC } & 1.9 & .0 & .2 & 2.0 \\ \text { U.S. } & -.1 & -.1 & .4 & .2 \\ \text { Japan } & .2 & 1.4 & .2 & 1.9 \\ \text { Canada } & -.0 & -.0 & .4 & .3 \\ \text { Other Developed } & -.6 & -.3 & -.2 & -1.0 \\ \text { OPEC } & .4 & .1 & -.1 & .5 \\ \text { NIC } & -.7 & -.1 & -.1 & -.9 \\ \text { LDC } & -2.1 & .2 & -.2 & -2.1 \\ \text { Total } & -1.1 & 1.3 & .7 & .8\end{array}$

B. Terms of Trade Impacts (\% change, tve indicates improvement)

$\begin{array}{lrrrr}\text { EEC } & .81 & .01 & .07 & .85 \\ \text { U.S. } & -.13 & -.13 & .14 & -.10 \\ \text { Japan } & .13 & .44 & .23 & .93 \\ \text { Canada } & -.12 & -.05 & -.42 & -.74 \\ \text { Other Developed } & -.34 & -.17 & -.11 & -.60 \\ \text { OPEC } & -.11 & .05 & -.07 & -.13 \\ \text { NIC } & -.44 & -.16 & -.10 & -.70 \\ \text { LDC } & -.77 & .07 & -.04 & -.74\end{array}$


which are exports by these regions to the U.S. The effect of moving from a destination to an origin basis is to move the tax from one where exports leave tax free, to one where a tax applies to exports. Given that both the EEC and Japan are not treated in the model as small open price taking economies, a significant terms of trade improvement occurs and the U.S. Is made worse off.

This feature operates in the opposite direction, in the Canadian case. In Canada, tax rates are also heavily concentrated on manufacturing, but the switch in tax basis produces a terms of trade improvement for the U.S., and a terms of trade worsening for Canada. This occurs because Canada is an exporter of raw materials andnatural resources and a net import of manufactures in U.S.-Canadian trade. The welfare gain to Canada, in spite of a terms of trade loss, occurs because of the compounding effect of the destination basis tax with tariffs and NTBs. This reversed trade pattern from the U.S.-EEC and U.S.-Japanese cases is thus crucial in determining whether the U.S. gains or loses from a basis switch. This table therefore produces the important policy implication that it may not be in the interest of the U.S. to persuade trading partners to switch from the existing destination basis to an origin basis in their indirect tax systems. In fact, in two of the three cases where the bilateral trade pattern has the U.S. as a net importer of manufactures, there is a welfare loss for the U.S. associated with such a switch. The policy implication is clearly that whether or not the U.S. should push for trading partners to switch to an origin basis depends crucially on the bilateral pattern of trade.

Similar results also occur where all three regions simultaneously switch to an origin basis from a destination basis. There is a terms of trade improvement for the EEC and Japan, and a terms of trade deterioration for Canada. The net effect for the U.S. is a small terms of trade gain, but the gain is smaller than that which would occur with a switch in Canada alone. 
Table 5 moves beyond the tax basis switch issue, reporting results from cases where indirect taxes in these three trading regions are abolished. The EEC abolishes the value added tax, Japan abolishes the commodity tax and Canada abolishes both the provincial retail sales tax and the manufacturing sales tax. As in Table 4, the welfare impacts of these changes are relatively small, but typically the aggregate effects are more significant than in the case of basis switches. Interestingly, the EEC loses from the abolition of the value added tax, Japan gains fromithe abolition of the commodity tax, and Canada gains from the abolition of the provincial retail sales tax and the manufactures sales tax.

Underlying these results are the terms of trade effects. In all three cases the tax removing country suffers a deterioration in their terms of trade. The net effect in the Japanese and Canadian case is a welfare gain, whereas in the EEC case a welfare loss occurs.

The reason for the terms of trade deterioration against the tax removing region is that manufacturing products are heavily taxed, and so the abolition of indirect taxes results in a substantial increase in production of manufacturing items in these regions. Manufacturing items are substantially more import intensive than non manufactures, and the increase in imports results in a terms of trade deterioration. All three regions thus suffer a terms of trade deterioration irrespective of the pattern of their trade with the U.S. On top of this is the welfare gain from the abolition of the tax, because of the removal of the domestic distortion. In the Japanese and Canadian cases this more than offsets the terms of trade deterioration, in the EEC case it less than offsets. 
Table 5

\section{Abolition of Indirect Taxes Abroad}

A. Annual Welfare Impacts (EV's in 1977 \$bill)

EEC Abolish Japan Abolish Canada Abolish

VAT Commodity tax

$-1.0$

EEC

U.S.

Japan

Canada

Other Developed

OPEC

NIC

LDC

Total
.0

$-.0$

.0

1.0

.6

$-.0$

.1

.6
.0

\section{PRST + MST}

.1

.8

.1

.5

$-.2$

.1

$-.0$

$-.0$

1.3

2.3
Al1 3 Change

Simultaneously

$$
-.9
$$

1.0

1.2

.5

.8

1.2

.1

.4

4.2

B. Terms of Trade Impacts (\% change, tve indicates improvement)

$\begin{array}{lrrrr}\text { EEC } & -.66 & .00 & .04 & -.60 \\ \text { U.S. } & .01 & -.00 & .31 & .34 \\ \text { Japan } & -.03 & -.74 & .14 & -.73 \\ \text { Canada } & .03 & .06 & -.82 & -.83 \\ \text { Other Developed } & .49 & -.03 & -.16 & .33 \\ \text { OPEC } & .48 & .39 & .02 & .88 \\ \text { NIC } & -.02 & -.03 & -.12 & -.15 \\ \text { LDC } & -.01 & .11 & -.01 & .11\end{array}$


A significant terms of trade gain accrues to OPEC in both the EEC and the Japanese tax removal cases. Removal of the taxes increases manufacturing production and also oil imports. Because these regions are so much larger than Canada, a removal of taxes in these cases is enough to give a substantial terms of trade improvement to OPEC.

Table 6 looks at a further set of changes where instead of removing taxes in U.S. trading partners, these taxes are instead added to existing U.S. excise and sales taxes (which are relatively small). In all cases a significant terms of trade improvement occurs for the U.S. However, because of the distorting nature of these taxes in the Japanese and Canadian cases, the net effect for the U.S. is a welfare loss because of the domestic distortions generated by the tax. The reason for the terms of trade improvement for the U.S. in these cases stems from the anti-manufacturing structure of indirect taxes in all three regions. In trade with both the EEC and Japan, the U.S. is a manufacturing importer, and since manufactures tend to be import intensive a tax which discriminates against manufactures, as these taxes do, will improve the U.S. terms of trade.

Table 7 considers some further cases where the taxes involved are abolished on domestic products only. Because the taxes are administered on a destination basis, removing taxes on domestic products only means that the tax degenerates to a tariff. In all cases large terms of trade gains occur for the region concerned, especially in the EEC case where a sharp welfare improvement also results. This substantiates the intuition claimed for Figure 2 regarding the differences between tariffs and discriminatory domestic taxes on either an origin or destination basis. These results also emphasize the earlier point, that the impacts of changes in tariffs are typically larger than changes in tax bases. 
Table 6.

Additions to Existing U.S. Excise and State Sales Taxes

A. Annual Welfare Impacts (EV's in \$bill 1977)

Add the Add the Japanese Add the Canadian

EEC VAT

EEC

$$
-.0
$$

U.S.

Japan

Canada

other Developed

OPEC

NIC

LDC

Total
Commodity Tax

PRST and MST

$\begin{array}{rr}-.6 & -.7 \\ -1.5 & -1.0 \\ -.7 & -.8 \\ -.9 & -1.0 \\ -.1 & -.1 \\ -.9 & -1.0 \\ -.2 & -.3 \\ .3 & .1 \\ -4.6 & -4.9\end{array}$

B. Terms of Trade Impacts (\%change, tve indicates improvement)

$\begin{array}{lrrr}\text { EEC } & -.02 & -.26 & -.29 \\ \text { U.S. } & .27 & 1.84 & 2.21 \\ \text { Japan } & -.07 & -.68 & -.75 \\ \text { Canada } & -.22 & -1.70 & -1.99 \\ \text { Other Developed } & .03 & -.02 & -.03 \\ \text { OPEC } & -.24 & -.44 & -.50 \\ \text { NIC } & .09 & -.11 & -.17 \\ \text { LDC } & .10 & .15 & .06\end{array}$


Table 7

Abolishing Taxes on Domestic Products Only

A. Annual Welfare Impacts (EV's in \$bill 1977)

In the EEC In Japan In Canada In Al1 3 Regions

$\begin{array}{lrrrr}\text { EEC } & 8.3 & .1 & -.1 & 8.1 \\ \text { U.S. } & -.5 & -.1 & -.2 & -.7 \\ \text { Japan } & .3 & 2.5 & -.0 & 2.8 \\ \text { Canada } & -.2 & -.0 & 1.4 & 1.2 \\ \text { Other Developed } & -5.1 & -.2 & -.1 & -5.3 \\ \text { OPEC } & -2.9 & -.2 & -.0 & -3.1 \\ \text { NIC } & -.8 & -.2 & -.1 & -1.1 \\ \text { LDC } & -1.9 & -.3 & .0 & -2.1 \\ \text { Total } & -2.7 & 1.5 & .9 & -2.1\end{array}$

B. Terms of Trade Impacts (\%change, tve indicates improvement)

$\begin{array}{lrrrr}\text { EEC } & 4.26 & .03 & -.02 & 4.14 \\ \text { U.S. } & -.28 & -.09 & -.19 & -.54 \\ \text { Japan } & .35 & .95 & -.02 & 1.33 \\ \text { Canada } & -.35 & -.03 & 1.41 & 1.09 \\ \text { Other Developed } & -2.51 & -.15 & -.10 & -2.69 \\ \text { OPEC } & -2.59 & -.23 & -.04 & -2.82 \\ \text { NIC } & -.55 & -.18 & -.14 & -.85 \\ \text { LDC } & -.85 & -.10 & -.00 & -.93\end{array}$


Pinally, in Table 8, some sensitivity analyses are reported for the case considered in Table, 4. where the EEC switches to an origin basis. In this table, different elasticity configirations in the model are used, but the welfare and ... terms of trade effects for the various regions remain largely insensitive to these changes. This suggests reasonable robustness of the policy conclusions with respeêt to alternative specifications of the model, although a more extensive investigation would be needed to confirm this for other cases.

\section{Conclusions and Policy Implications}

In this paper a numerical general equilibrium model of world trade has been used to analyze the impacts of border adjustments in indirect taxes used by major U.S. trading partners on U.S. trade and welfare. The policy setting for the analysis is the continuing U.S. concern over the destination basis in the Value Added Tax in the EEC, and the wider set of concerns that the U.S. operates in a trading environment in which other partners use broadly based indirect taxes on a destination basis while the U.S. has no comparable tax. The paper explicitly attempts to move away from earlier theoretical literature on the uniform tax rate case where neutrality propositions prevail for tax basis switches, to incorporate the non-uniform taxes which prevall in practice.

Results indicate that a move from the existing destination basis to an origin basis is welfare worsening for the U.S. if this were done in either the EEC or Japan, but would be welfare improving if this were done in Canada. What this reflects is that foreign taxes abroad tend to be heavily concentrated on manufactures, and if the U.S. is a net importer of manufactures from the region concerned a terms of trade improvement accrues to the foreign trading partner. Thus, for the U.S. to argue 
TABLE 8

Sensitivity Analys1s for ERC Switch to Origin Basis (Case 1, Tabie 5)

A. Annual Welfare Impacts (EV's in \$b111, 1977)

\begin{tabular}{|c|c|c|c|c|c|c|c|c|c|}
\hline & $\begin{array}{c}\text { Case } 1, \\
\text { Table } 1 \\
\text { central case } \\
\text { opeciflcation) }\end{array}$ & $\underset{A}{\operatorname{Varlation}}$ & $\underset{B}{\operatorname{Variation}}$ & $\underset{c}{\operatorname{Varfation}}$ & $\begin{array}{c}\text { Variation } \\
D\end{array}$ & $\underset{E}{\text { Vartation }}$ & $\underset{\mathbf{F}}{\text { Variation }}$ & $\begin{array}{c}\text { Variation } \\
\mathbf{G}\end{array}$ & $\underset{H}{\operatorname{Variation}}$ \\
\hline ERC & 1.9 & 1.3 & 1.6 & 1.4 & 1.7 & 2.1 & 1.9 & 2.1 & 1.5 \\
\hline o.s. & -.1 & .3 & .0 & -.2 & -.2 & -.2 & -.2 & -.2 & -.1 \\
\hline Japan & .2 & .4 & .3 & .0 & .2 & .3 & .2 & .2 & .3 \\
\hline Canada & -.0 & .1 & .0 & -.0 & -.0 & .0 & -.0 & -.0 & .0 \\
\hline Other Developed & -.6 & -.6 & -.7 & -.2 & -.4 & -.8 & -.7 & -.7 & -.4 \\
\hline OPEC & .4 & .4 & .4 & .3 & .3 & .4 & .4 & .4 & .6 \\
\hline NIC & -.7 & -.5 & -.6 & -.7 & -.7 & -.8 & -.7 & -.6 & -.5 \\
\hline LDC & -2.1 & -1.7 & -1.8 & -2.1 & -2.1 & -2.2 & -2.1 & -2.1 & -2.5 \\
\hline TOTAL & -1.1 & -.3 & -.7 & -1.5 & -1.2 & -1.1 & -1.1 & -1.0 & -1.1 \\
\hline
\end{tabular}

B. Terms of Trade Effects (\% change, tve Indicates improvement)

$\begin{array}{lrrrrrrrrr}\text { EEC } & .81 & .79 & .78 & .76 & .77 & .90 & .83 & .84 & .70 \\ \text { J.S. } & -.13 & -.14 & -.13 & -.13 & -.13 & -.16 & -.13 & -.13 & -.10 \\ \text { Japan } & .13 & .37 & .29 & -.07 & .09 & .26 & .11 & .11 & .21 \\ \text { Canada } & -.12 & .02 & -.03 & -.13 & -.10 & -.08 & -.13 & -.13 & -.09 \\ \text { Other Developed } & -. .34 & -.48 & -.42 & -.21 & -.26 & -.41 & -.34 & -.35 & -.29 \\ \text { OPEC } & -.11 & -.24 & -.18 & -.19 & -.14 & -.08 & -.11 & -.13 & -.10 \\ \text { NIC } & -.44 & -.50 & -.48 & -.35 & -.43 & -.56 & -.44 & -.44 & -.43 \\ \text { IDC } & -.77 & -.55 & -.63 & -.58 & -.72 & -.94 & -.77 & -.77 & -.75\end{array}$

Variation A: Elasticities of Substitution (ES) between Import types in both intermediate and final demands set equal to 5.0 in all reglons. 1

Varlation B: As for A but 3.0 rather than 5.0 used. ${ }^{1}$

Variation C: ES between Import composites and domestic produsts in both intermediate and firial demands set equal to 3.0 in all regions. 2

Variation D: As for $C$ but 1.5 rather than 3.0 used. 2

Varlation E: As for $C$ but 0.75 rather than 3.0 used. 2

Varlaticn F: Income elasticities in final impcrt demands displaced from unity; 0.9 in regicns $1-6$ $1.1 \ln 7,8^{3}$

Variation G: As for E but 0.75 used in regions $1-6,1.25$ in $\%, 8,3$

Varlation $H$ : $\Lambda$ s for $E$ but 1.5 used in all reglons. 3

1

2 Values of 1.5 are used in the central case

Different values by region are used in the central case. These are based on 3 1iterature estimates and are in the range $0.9-1.5$

Values of 1.0 are used in the central case. 
strongly in favour of having all trading partners switch to an origin basis seems misplaced on the basis of the calculations reported here. Results also portray the tax basis issue as being less significant than other trade protection issues involving tariffs and non-tariff barriers. 


\section{BIBLIOGRAPHY}

Brown, F., and J. Whalley (1980) "General Equilibrium Evaluations of Tariff Cutting Proposals in the Tokyo Round and Comparisons with more Extensive Liberalization of World Trade" Economic Journal, December, Vo1. 98, pp. 838-866.

Grossman, G.M. (1980) "Border tax adjustments: Do they distort trade? Journal of International Economics, November, Vol. 10 No. 4, pp. 117

Khan, M.S. (1974) "Import and Export Demand in Developing Countries" IMF Staff Papers, November 1974, pp. 678-693.

Krauss, M. and H.G. Johnson (1970) "Border Taxes, Border Tax Adjustments, Comparative Advantage, and the Balance of Payments." Canadian Journal of Economics, November, Vol. 3 No. 4, pp. 595-602.

Mansur, A.H. and J. Whalley (1983) "Numerical Specifications of Applied General Equilibrium Models: Estimation, Calibration, and Data." H.E. Scarf and J.B. Shoven (eds). Applied General Equilibrium Analysis, Cambridge University Press.

Meade, J.E. (1974) "A Note on Border-Tax Adjustments" Journal of Political Economy, Vol. 82 No. 5, pp. 1013-1015.

Shibata, H. (1967) "The theory of economic unions: A comparative analysis of customs unions, free trade areas, and tax unions" in: C.S. Shoup, ed., Fiscal harmonization in common markets, Vol. I, Theory (Columbia University Press, New York).

Shoup, C.S. (1969) Public Finance (Weidenfeld and Nicolson, London).

Stern, R.M., J. Francis, and B. Schumacher (1977) Price Elasticities in International Trade: An Annotated Bibliography, Macmillan, for the Trade Policy Research Centre, London.

Stone, J.A. (1979) Price Elasticities of Demand for Imports and Exports: Industry Estimates for the U.S., the EEC, and Japan, Review of Economics and Statistics, Vol. LXI, May, pp. 306-312.

Vandendorpe, A.L. and A.F. Friedlaender (1968) "Excise taxes and gains from trade." Journal of Political Economy, Vo1. 76, pp. 1058-1068.

Whalley, J. (forthcoming) Trade Liberalization Among Major World Trading Areas (MIT Press). 
$8101 C$

$8102 \mathrm{C}$

$8103 C$

$8104 \mathrm{C}$

$8105 \mathrm{C}$

$8106 C$

$8107 C$

$8108 C$ D gl

8109 C D

$8110 \mathrm{C}$

$8111 \mathrm{C}$

1982

$8201 C$

$8202 C$

$8203 C$

$8204 C$

$8205 \dot{C}$

$8206 C$

$8207 C$

$8208 C$ A Survey of Some Cases. Industries: Some Empirical Evidence. Some Australian Evidence. Comparative Advantage Long Run Production Possibilities Committed Firms Applied General Equilibrium Approach UTI LI ZATI ON IN GENERAL EQUILIBRI UM and Elasticity Pessimism.

Markusen, James R. Factor Movements and Commodity Trade as Compliments:

Conlon, R.M. Comparison of Australian and Canadian Manufacturing

Conlon, R.M. The Incidence of Transport Cost and Tariff Protection:

Laidler, David. On the Case for Gradualism.

Wirick, Ronald G. Rational Expectations and Rational Stabilization Policy in an Open Economy

Mansur, Ahsan and John Whalley Numerical \$pecification of Applied General Equilibrium Models: Estimation, Calibration, and Data.

Burgess, David F., Energy Prices, Capital Formation, and Potential GNP Jimenez, E. and Douglas $\mathrm{H}$ Keare. Housing Consumption and Income in the Low Income Urban Setting: Estimates from Panel Data in El Salvador

Whalley, John Labour Migration and the North-South Debate

Manning, Richard and John McMillan Government Expenditure and

Freid, Joel and Peter kowitt Why Inflation Reduces Real I nterest Rates

Manning, Richard and James R. Markusen Dynamic Non-Substitution and

Feenstra, Robert and Ken Judd Tariffs, Technology Transfer, and Welfare

Ronald W. Jones, and Douglas D. Purvis: International Differences in Response to Common External hocks: The Role of Purchasing Power Parity

James A Brander and Barbara J. Spencer: Industrial Strategy with

Whalley, John, The North-South Debate and the Terms of Trade: An

Roger Betancourt, Christopher Clague, Arvind Panagariya CAPI TAL

Mansur, Ahsan $\mathrm{H}$, On the Estimation of Import and Export Demand Elasticities

Whalley, J. and Randy Wigle PRICE AND QUANTITY RIGIDITIES IN ADJUSTMENT TO TRADE POLICY CHANGES: ALTERNATIVE FORMULATIONS AND INITJAL CALCULATIONS

8209C DSU Jimenez, E. SQUATTING AND COMMUNITY ORGANIZATION IN DEVELOPING COUNTRIES: A CONCEPTUAL FRAMEWORK 
8210C Grossman, G.M. INTERNATIONAL COMPETITION AND THE UNIONIZED SECTOR

8211C Laidler,D. FRIEDMAN AND SCHWARTZ ON MONETARY TRENDS - A REVIEW ARTICLE

8212C Imam, M.H. and Whalley, J. INCIDENCE ANALYSIS OF A SECTOR SPECIFIC MINIMUM WAGE IN A TWO SECTOR HARRIS-TODARO MODEL.

8213C Markusen, J.R. and Melvin, J.R. THE GAINS FROM TRADE THEOREM WITH INCREASING RETURNS TO SCALE.

8214C INDUSTRIAL ORGANIZATION AND THE GENERAI, EQUILIBRIUM COSTS OF PROTECTION IN SMALL OPEN ECONOMIES.

8215C Laidler, D. DID MACROECONOMICS NEED THE RATIONAL EXPECTATIONS REVOLUTION?

8216C Whalley, J. and Wigle, R. ARE DEVELOPED COUNTRY MULTILATERAL TARIFF REDUCTIONS NECESSARILY BENEFICIAL FOR THE U.S.?

8217C Bade, R. and Parkin, M. IS STERLING M3 THE RIGHT AGGREGATE?

8218C Kosch, B. FIXED PRICE EQUTLIBRIA IN OPEN ECONOMIES.

\section{3}

8301C Kimbell, L.J. and Harrison, G.W. ON THE SOLUTION OF GENERAL EQUILIBRIUM

8302C Melvin, J.R. A GENERAL EQUILIBRIUM ANALYSIS OF .CANADIAN OIL POLICY.

8303C Markusen, J.R. and Svensson, L.E.0. TRADE IN GOODS AND FACTORS WITH INTERNATIONAL DIFFERENCES IN TECHNOLOGY.

$8304 \mathrm{C}$ Mohammad, S. Whalley, J. RENT SEEKING IN INDIA: ITS COSTS AND POLICY SIGNIFICANCE.

8305C DSU Jimenez, E. TENURE SECURITY AND URBAN SỌUATING.

8306C Parkin, M. WHAT CAN MACROECONOMIC THEORY TELL US ABOUT THE WAY DEFICITS SHOULD BE MEASURED.

8307C Parkin, M. THE INFLATION DEBATE: AN ATTEMPT TO CLEAR THE AIR.

8308C Wooton, I. LABOUR MIGRATION IN A MODEL OF NORTH-SOUTH TRADE.

8309C Deardorff, A.V. THE DIRECTIONS OF DEVELOPING COUNTRIES TRADE: EXAMPLES FROM PURE THEORY.

8310C Manning, R. ADVANTAGEOUS REALLOCATIONS AND MUTTIPLE EQUILIBRIA: RESULTS FOR THE THREE-AGENT TRANSFER PROBLEM. 
8311C DSU Mohammad, S. and Whalley, J. CONTROLS AND THE INTERSECTORAL TERMS OF TRADE IN INDIA.

8312C Brecher, Richard $A$. and Choudhri, Ehsan U. NEW PRODUCTS AND THE FACTOR CONTENT OF INTERNATIONAL TRADE.

8313C Jones, R.W., Neary, J.P. and Ruane, F.P. TWO-WAY CAPITAL FLOWS: CROSSHAULING IN A MODEL OF FOREIGN INVESTMENT.

8314C DSU Follain, J.R. Jr. and Jimenez, E. THE DEMAND FOR HOUSING CHARACTERISTICS IN DEVELOPING COUNTRIES.

8315C Shoven, J.B. and Whalley, J. APPLIED GENERAL EQUILIBRIUM MODELS OF TAXATION AND INTERNATIONAL TRADE.

8316C Boothe, Paul and Longworth David. SOME IRREGULAR REGULARITIES IN THE CANADIAN/U.S. EXCHANGE MARKET.

8317C Hamilton, Bob and Whalley, John. BORDER TAX ADJUSTMENTS AND U.S. TRADE.

8318C Neary, J. Peter, and Schweinberger, Albert G. FACTOR CONTENT FUNCTIONS AND THE THEORY OF INTERNATIONAL TRADE. 